\title{
Application of Tissue Culture Technique on Marrubium vulgare L. Plant
}

\author{
Abdallah, S. A. S.; H. M. S. Hassan; M. A. El-Mekawy and N. A. M. Ali \\ Plant Production Department, Faculty of Environmental Agricultural Sciences, Arish University
}

\section{Received: $6 / 2 / 2018$}

\begin{abstract}
This study was carried out at the Plant Tissue Culture Laboratory, Faculty of Environmental Agricultural Sciences (FEAS), Arish University, North Sinai, Egypt during 2012 to 2017 . The aim of the study was to use tissue culture technique for the micropropagation of Marrubium vulgare plant. One node cutting and shoot tip were cultured on MS, NN and B5 media supplemented with $100 \mathrm{mgl}^{-1}$ myo-inositol and $3 \%$ sucrose. The results showed that shoot tip cultured on the MS medium had the best effect on the establishment stage of mother plants. Multiple shoots were obtained on MS medium supplemented with $1.00 \mathrm{mgl}^{-1} \mathrm{Kin}_{\text {in }}$ combination with $0.10 \mathrm{mgl}^{-1} \mathrm{NAA}$. MS medium supplemented with $0.30 \mathrm{mgl}^{-1}$ pyridoxine achieved the best shoot development compared with the other additive treatments and control. The highest rooting of shoots was with full strength MS medium supplemented with $1.00 \mathrm{mgl}^{-1} \mathrm{IBA}$ and half strength MS medium with $1.50 \mathrm{mgl}^{-1}$ NAA. Hardening the rooted cuttings was done in a greenhouse in pots containing a mixture of peatmoss, vermiculite and washed sand at the rate of $1: 1: 1(\mathrm{v} / \mathrm{v} / \mathrm{v})$. Plantlets were successfully acclimated with $90 \%$ survival.
\end{abstract}

Keywords: Marrubium vulgare L., micropropagation, explant, media and additives

\section{INTRODUCTION}

Family Labiates (Lamiaceae) contains 221 genera and 200 species, distributed in central Asia and the Mediterranean region (Harley et al., 2004). Plants of this family are shurbs, subshurbs, herbs, but rarely trees (Ghazanfer, 1994). The Lamiaceae plants was considered as one of the largest plant families used as a framework to evaluate the occurrence of typical secondary metabolites (Wink, 2003). M. vulgare (white horehound or common horehound) is a flowering plant in the mint family (Lamiaceae), native to Europe northern Africa, and southwestern and central Asia. It is also widely naturalized in many places, including most of North and South America (Wiesnerand Peikert, 2013).

M. vulgare plant used in folk cure to possess hypoglycemic (Roman et al., 1992), vasorelaxant (ELBardai et al., 2003), antihypertensive (EL-Bardai et al., 2004), analgesic (Desouza, 1998; Sahpaz et al., 2002), anti-inflammatory (Schlemper et al., 1996), antioxidant (Weel, 1999; kadri et al., 2011), antiede-matogenic activity (Stulzer et al., 2006) and many other biological activities. Moreover, extracts of this plant have shown some effects on type-II diabetes (Boudjelal et al., 2012).

By traditional mode of propagation from a single plant, like cuttings and air layering, less number of plants is produced taking more time and encountered sometimes with difficulties such as fungal, bacterial and viral diseases (Chase, 1987). Therefore, the use of tissue cultured micropropagated plantlets can obviously offer more number of plants within a relatively short period (Khan et al., 2004).

So that this study aimed to establish an applicable protocol to save the endangered native Egyptian Marrubium vulgare plant through in vitro micropropagation.

\section{MATERIALS AND METHODS}

This study was carried out at the Plant Tissue Culture Laboratory at the Faculty of Environmental
Agricultural Sciences, Arish University, North Sinai, Egypt to study the micropropagation of Marrubium vulgare plant by using different media $(\mathrm{MS}, \mathrm{NN}$, and B5) and different additives (Argininen, asparagines, pyridoxine and thiamine) on the best medium (MS) with $1.00 \mathrm{mgl}^{-1} \mathrm{Kin}$ in combination with $0.10 \mathrm{mgl}^{-1}$ NAA.

\section{Establishment stage: Plant material:}

Marrubium vulgare L. seeds were collected from wild mature plants grown in North Sinai by Research Station (El-Sheikh Zuwyed), Desert Research Center (DRC). Explants from germinated seeds were cut into small cuttings included shoot tip and nodal segments in length of $0.50-1.00 \mathrm{~cm}$

\section{Seeds sterilization:}

Seeds were washed under running tap water for 60 minutes with a few drops of liquid soap and washed with sterilized distilled water for 5 minutes. The seeds were soaked for 10 minutes in $20 \%$ Clorox (containing $5.25 \%$ sodium hypochlorite with two drops of Tween$20)$ then washed again with sterilized distilled water for 3-5 times to remove all traces of the disinfectant. 10 seeds were placed on MS Medium in jars and incubated in a growth chamber at $18 \pm 2{ }^{\circ} \mathrm{C}$ in the dark. After 7 days these were transferred under $16 / 8$ photoperiod at $25 \pm 2{ }^{\circ} \mathrm{C}$.

\section{Culture media:}

The MS, NN and B5 media containing macro and micro elements as well as vitamins, according to Murashige and Skoog (1962), Nitsch and Nitsch (1969) and Gamborg et al. (1968) media were tested. The media were supplemented with $100 \mathrm{mgl}^{-1}$ myo-inositol and $3 \%$ sucrose. All media were adjusted to $\mathrm{pH} 5.70$ 5.80 using either $0.10 \mathrm{~N} \mathrm{NaOH}$ or $0.10 \mathrm{~N}$ HCL before gelling with $7.00 \mathrm{gml}^{-1}$ agar. The media were dispensed into glass tissue culture jars each jar contained $15 \mathrm{ml}$ of culture medium. All media were autoclaved at $121^{\circ} \mathrm{C}$ and $1.06 \mathrm{~kg} / \mathrm{cm}^{2}$ for $20 \mathrm{~min}$. The jars were transferred to the culture cabinet and left cool in a slanted position till they were used. 


\section{Medium type:}

MS, NN and B5media were tested through this study to select the best medium type that induces the highest explants development from shoot tip explant.

\section{Explants type:}

Shoot-tips and one -node cutting $0.50-1.00 \mathrm{~cm}$ of 30 days old seedlings were excised and cultured on MS, NN and B5 media to select the best explants type which encourage the highest explant development.

\section{Culture conditions:}

The sterilized explants were cultured on the media under complete aseptic conditions in the Laminar airflow cabinet, then the cultured explants were incubated under $16 \mathrm{hr}$ of artificial light and $8 \mathrm{hrs}$ of dark at average temperature of $25 \pm 2^{\circ} \mathrm{C}$ provided by cool white fluorescent lamps (light intensity 2000 lux) for all experiments and the data were recorded after 4 weeks.

Multiplication stage:

This stage aimed to increase the number of shoots, so that the growth obtained from the establishment stage was used as explants during the multiplication experiments.

\section{Effect of cytokinin types:}

Kinetin (Kin), 6-benzyladenine (BA) and 2isopentenyl adenine $(2 \mathrm{iP})$ were studied at the rate of $1.00 \mathrm{mgl}^{-1}$ to determine the best cytokinin that induces the highest multiplication.

\section{Effect of different Kin concentrations:}

Different Kin concentrations $(0.00,0.05,0.10$, 1.50 and $\left.2.00 \mathrm{mgl}^{-1}\right)+0.10 \mathrm{mgl}^{-1}$ NAA were evaluated to determine the most suitable concentration that induces the highest multiplication.

\section{Effect of amino acids and vitamines additive:}

Arginine, asparagines, pyridoxine and thiamine were added to the culture MS medium at the level of $0.20 \mathrm{mgl}^{-1}$ to detect the most effective additive that maximize explants development and growth of $M$. vulgare. After the previous experiments the best additive were used at different concentrations. For Marrubium vulgare, pyridoxine was the best one at a concentration of $0.30 \mathrm{mgl}^{-1}$.

\section{Rooting stage:}

The proliferated shoots of Marrubium vulgare were used as explants and cultured on MS supplemented with $100 \mathrm{mgl}^{-1}$ myo-inositol, $30.0 \mathrm{gl}^{-1}$ sucrose and 7.00 $\mathrm{gl}^{-1}$ agar. Also, shoots were grown on plant growth regulators (PGRs) free MS for 4 weeks to eliminate any carry over effect of any PGRs that might inhibit or reduce rooting.

\section{Effect of medium strength and auxin type:}

Shoots of 3-4 cm long were excised from the proliferated shoots and cultured on full, half and quarter strengths of MS basal medium supplemented with 1.00 $\mathrm{mgl}^{-1} \mathrm{IBA}, 1.00 \mathrm{mgl}^{-1} \mathrm{NAA}$ or $1.00 \mathrm{mgl}^{-1}$ IAA to determine the best media strength and type of auxin that enhance root formation in Marrubium vulgare.

\section{Effect of IBA and IAA concentrations:}

Shoots were cultured on full strength and half strength of MS media with different concentrations $\left(0.00,0.50,1.00,1.50\right.$ and $\left.2.00 \mathrm{mgl}^{-1}\right)$ for both IBA and NAA to investigate the suitable concentration which encourages the highest root formation.

\section{Acclimatization stage:}

Well rooted plantlets were removed from the jars. The roots of the chosen plantlets were washed thoroughly with running tap water to get rid of residues. Then the roots were washed with sterilized distilled water after removing dead leaves and dry shoots of plantlets. Plantlets were surface sterilized by soaked in a fungicide solution of rizolex $(1 \mathrm{gm} / \mathrm{l})$ for 3-5 min., The roots were washed with sterilized distilled water and planted in black polyethylene pots $8 \mathrm{~cm}$ in diameter filled with three mixtures as follow: 1) $1: 1: 1(\mathrm{v} / \mathrm{v} / \mathrm{v})$ peat moss, vermiculite and sand; 2) with 1:1:1 (v/v/v) peat moss, vermiculite and perlite; and 3) 1:1 (v/v) peat moss, vermiculite for Marrubium vulgare, then covered with white transparent bags having small holes which were made after one week and the size of these holes was increased gradually until the plantlet become suitable for transferring to the bigger pots $(30 \mathrm{~cm}$ diameter) and when plantlets produced new leaves they were transferred from greenhouse eventually to field conditions.

\section{Statistical analysis}

The design of the experiments was completely randomized, sometimes in a layout of factorial according to the studied factors in every experiment. Data were tested using the analysis of variance (ANOVA) by the General Linear Models (GLMs) procedures using SAS (SAS, 2004). The significant differences were observed for the measured value, means were separated using Duncan's multiple range test (DMRT) (Duncan, 1955) at the $0.05 \%$ level.

\section{RESULTS AND DISCUSSION}

\section{Establishment stage:}

\section{Effect of medium type:}

Data in Table (1) show that the MS medium achieved the highest shoot number per explant, shoot length, and number of leaves $(4.58,3.16 \mathrm{~cm}$ and 22.17 , respectively) of Marrubium vulgare plant as compared with the other two media tested (Gamborg "B5" and Nitsch and Nitsch). These results are in agreement with Arafeh et al. (2003), Ozkum (2007), Oana et al. (2008), Oluk and Cakir (2009), El Beyrouthy et al. (2015) who found that using MS medium recorded the highest number of shoots, shoot length, number of leaves and number of leaves/shoot on different Origanum species. On the other hand, Yavuz (2015) found that using B5 medium was more effective than MS medium on in vitro propagated of Sideritis stricta plant. Also, Arikat et al. (2004) observed that shoot-tip from Salvia fruticosa plants cultured on B5 medium had the lowest number of shoots and leaves number compared to the MS medium. 
Table (1): Effect of medium types on shoot number per explant, shoot length, and number of leaves of Marrubium vulgare plant

\begin{tabular}{|c|c|c|c|}
\hline Medium type $\quad$ Parameters & $\begin{array}{l}\text { Shoot number } \\
\text { per explant }\end{array}$ & $\begin{array}{c}\text { Shoot } \\
\text { Length }(\mathrm{cm})\end{array}$ & $\begin{array}{l}\text { No. } \\
\text { Leaves }\end{array}$ \\
\hline MS & $4.58^{\mathrm{a}}$ & $3.16^{\mathrm{a}}$ & $22.17^{\mathrm{a}}$ \\
\hline B5 & $1.67^{\mathrm{b}}$ & $1.67^{b}$ & $1.67^{\mathrm{b}}$ \\
\hline $\mathbf{N N}$ & $1.67^{b}$ & $1.85^{\mathrm{b}}$ & $6.50^{\mathrm{b}}$ \\
\hline
\end{tabular}

Means followed by the same letter within each column are not significantly different at 0.05 level of probability according to Duncan's multiple range test

\section{Effect of explant type:}

Data tabulated in Table (2) show significant effect of explants type for all studied traits and shoot tip culture resulted in the highest shoot number per explant, shoot length, and number of leaves $(3.72,2.78$ $\mathrm{cm}$ and 13.68 , respectively) compared with one-node cutting of Marrubium vulgare plant. These results are supported by the findings of Arafeh et al. (2003), Goleniowski et al. (2003), and Oulk and cakir (2009). They found that the shoot tips recorded the highest number of shoots, shoots length and number of leaves on different Origanum species. On the other hand, Yildirim (2013), El Beyrouthy et al. (2015), Bakhtiar et al. (2016) indicated that one-node cutting achieved the highest explant development for different Origanum species. Also, Zuzarte et al. (2010) found that the highest number of shoots was achieved when using nodal segment explants compared to axillary buds on multiplied Lavandula pedunculata plants.

Table (2): Effect of explant type on shoot number per explant, shoot length, and number of leaves of Marrubium vulgare plant

\begin{tabular}{|c|c|c|c|c|}
\hline Explant types & Parameters & $\begin{array}{c}\text { Shoot number } \\
\text { per explant }\end{array}$ & $\begin{array}{c}\text { Shoot } \\
\text { Length }(\mathrm{cm})\end{array}$ & $\begin{array}{c}\text { No. } \\
\text { Leaves }\end{array}$ \\
\hline Shoot-tip & & $3.72^{\mathrm{a}}$ & $2.78^{\mathrm{a}}$ & $13.68^{\mathrm{a}}$ \\
\hline One-node cutting & & $1.56^{\mathrm{b}}$ & $1.67^{\mathrm{b}}$ & $6.48^{\mathrm{b}}$ \\
\hline
\end{tabular}

Means followed by the same letter within each column are not significantly different at 0.05 level of probability according to Duncan's multiple range test

\section{Effect of media and explant type:}

Data in Table 3 indicate that shoot-tip cultured on MS medium had significant effect on shoot number per explant, shoot length, and number of leaves compared with other treatments of Marrubium vulgare plant. However the shoot-tips which were cultured on NN and B5media produced the lowest shoot number per explant, shoot length, and number of leaves. This result may be due to the effect of MS medium which promote explants growth and the effect of shoot tip that produces a novel stock, which are free from pathogens viruses. The explanation is agreement with Thorpe (1981) who reported that the most important application of meristem culture is the production of pathogen-free plants, especially viruses, and also the longterm storage of such virus-free germplasm through cryopreservation technique. These results are supported by the findings of Arafeh et al. (2003), Yildirim (2013), El-Beyrouthy et al. (2015) and Bakhtiar et al. (2016) who found that the MS was the best medium with shoot-tip on Lamiaceae family plants.

Table (3): Effect of interaction between medium and explant types on shoot number per explant, shoot length, and number of leaves of Marrubium vulgare plant

\begin{tabular}{|c|c|c|c|c|}
\hline Medium \& explant type & Parameters & $\begin{array}{c}\text { Shoot number } \\
\text { per explant }\end{array}$ & $\begin{array}{c}\text { Shoot } \\
\text { Length }(\mathrm{cm})\end{array}$ & $\begin{array}{c}\text { No. } \\
\text { Leaves }\end{array}$ \\
\hline \multirow{2}{*}{ MS } & Shoot tip & $6.50^{\mathrm{a}}$ & $4.13^{\mathrm{a}}$ & $31.00^{\mathrm{a}}$ \\
\hline & One-node cutting & $2.67^{\mathrm{b}}$ & $2.19^{\mathrm{bc}}$ & $13.33^{\mathrm{b}}$ \\
\hline \multirow{2}{*}{ B5 } & Shoot tip & $2.33^{b}$ & $1.67^{\mathrm{cd}}$ & $2.33^{\mathrm{d}}$ \\
\hline & One-node cutting & $1.00^{\mathrm{c}}$ & $1.67^{\mathrm{cd}}$ & $1.37^{\mathrm{d}}$ \\
\hline \multirow{2}{*}{$\mathbf{N N}$} & Shoot tip & $2.33^{b}$ & $2.53^{b}$ & $8.67^{\mathrm{c}}$ \\
\hline & One-node cutting & $1.00^{\mathrm{c}}$ & $1.16^{\mathrm{d}}$ & $4.33^{\mathrm{d}}$ \\
\hline
\end{tabular}

Means followed by the same letter within each column are not significantly different at 0.05 level of probability according to Duncan's multiple range test 


\section{Multiplication stage}

Effect of cytokinin types:

Data in Table (4) and Fig. (1) show significant effects for cytokinin types on all studied traits. The highest records were with Kin for all traits without significant differences between control and 2ip for shoot length.
These results are in agreement with the findings of Arafeh et al. (2003) who found that Kin at $0.4 \mathrm{mgl}^{-1}$ gave the highest number of shoots per explant and number of leaves for $O$. syriacum. On the other side, ElBeyrouthy et al. (2015) observed that the BAP $1.5 \mathrm{mgl}^{-1}$ recorded to higher values of shoot length on $O$. syriacum.

Table (4): Effect of cytokinins type on shoot number per explant, shoot length, and number of leaves of Marrubium vulgare plant

\begin{tabular}{|c|c|c|c|c|}
\hline $\begin{array}{l}\text { Cytokinin type } \\
\left(1 \mathrm{mgl}^{-1}\right)\end{array}$ & Parameters & $\begin{array}{c}\text { Shoot number } \\
\text { per explant }\end{array}$ & $\begin{array}{c}\text { Shoot } \\
\text { Length (cm) }\end{array}$ & $\begin{array}{l}\text { No. } \\
\text { leaves }\end{array}$ \\
\hline Control (PGRs-free) & & $2.00^{\mathrm{b}}$ & $2.77^{b}$ & $15.00^{\mathrm{b}}$ \\
\hline Kin & & $3.00^{\mathrm{a}}$ & $4.50^{\mathrm{a}}$ & $25.33^{\mathrm{a}}$ \\
\hline 2ip & & $1.500^{\mathrm{b}}$ & $2.67^{b}$ & $12.00^{\mathrm{b}}$ \\
\hline BA & & $1.500^{\mathrm{b}}$ & $2.55^{\mathrm{b}}$ & $14.00^{\mathrm{t}}$ \\
\hline
\end{tabular}

Means followed by the same letter within each column are not significantly different at 0.05 level of probability according to Duncan's multiple range test

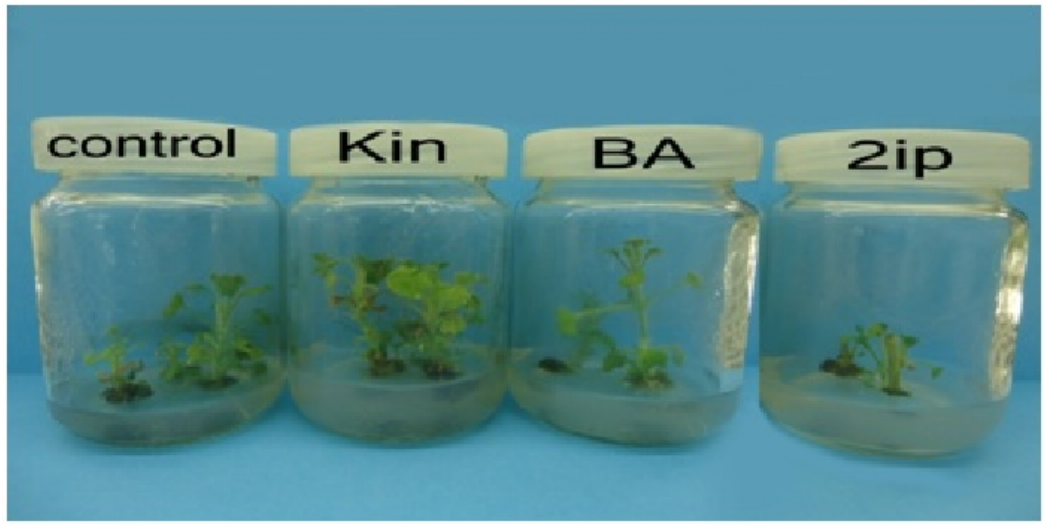

Fig. (1): Effect of Cytokinin type on Marrubium vulgare plant

\section{Effect of kinetin (Kin) concentrations:}

Data in Table (5) and Fig. (2) show significant effect for kinetin concentrations on all studied traits. Using $1.00 \mathrm{mgl}^{-1}$ of Kin resulted in the highest values for shoot number per explant, shoot length, and number of leaves. The lowest values for all studied traits were recorded with control. These results are in agreement with the findings of Ozudogru et al. (2011) found that $1.00 \mathrm{mgl}^{-1}$ Kin gave the highest number of shoots per explants on thymus vulgaris. However, Arafeh et al. (2003) who found that Kin at $0.4 \mathrm{mgl}^{-1}$ gave the highest number of shoots per explant on $O$. syriacum plant.

Table (5): Effect of kinetin concentrations plus $0.10 \mathrm{mgl}^{-1} \mathrm{NAA}$ on shoot number per explant, shoot length, and number of leaves of Marrubium vulgare plant

\begin{tabular}{|c|c|c|c|c|}
\hline Kin Conc. mgl $^{-1}$ & Parameters & $\begin{array}{c}\text { Shoot number } \\
\text { per explant }\end{array}$ & $\begin{array}{c}\text { Shoot } \\
\text { Length }(\mathrm{cm})\end{array}$ & $\begin{array}{c}\text { No. } \\
\text { leaves }\end{array}$ \\
\hline Control (PGRs-free) & & $1.40^{\mathrm{b}}$ & $1.41^{\mathrm{d}}$ & $8.60^{c}$ \\
\hline 0.50 & & $1.31^{\mathrm{b}}$ & $1.99^{\mathrm{c}}$ & $11.63^{\mathrm{bc}}$ \\
\hline 1.00 & & $2.14^{\mathrm{a}}$ & $3.57^{\mathrm{a}}$ & $24.71^{\mathrm{a}}$ \\
\hline 1.50 & & $1.20^{\mathrm{b}}$ & $2.75^{\mathrm{b}}$ & $13.87^{\mathrm{b}}$ \\
\hline 2.00 & & $1.50^{\mathrm{ab}}$ & $2.08^{c}$ & $11.57^{\mathrm{bc}}$ \\
\hline
\end{tabular}

Means followed by the same letter within each column are not significantly different at 0.05 level of probability according to Duncan's multiple range test 


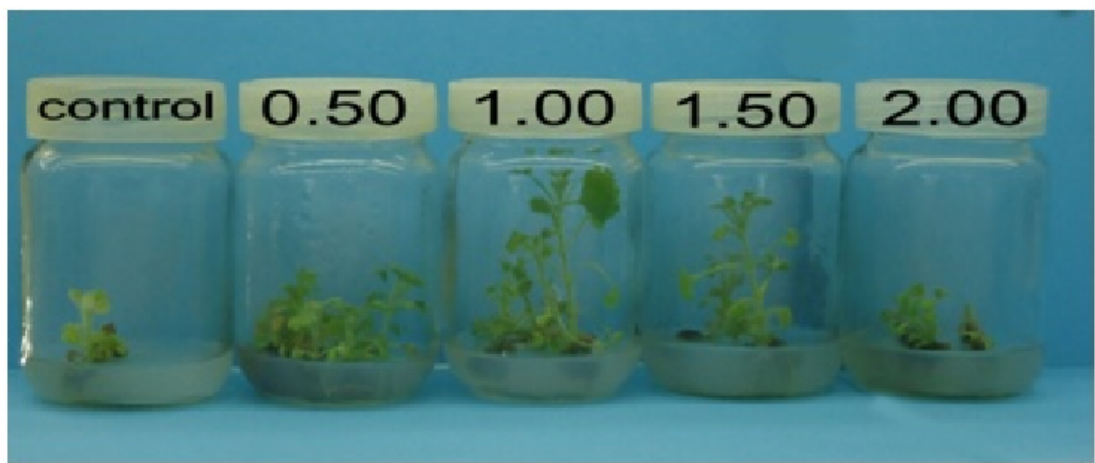

Fig. (2): Effect of kinetin concentrations on Marrubium vulgare plant

\section{Effect of additive:}

Adding pyridoxine resulted in the highest significant values of shoot number per explant, shoot length, and number of leaves (Table 6 and Fig. 3). Abdallah (2012) found that the opposite result the thiamine was effective in enhancing number of shoots, shoot length, number of leaves and number of leaves/shoot of Capparis spinosa. Also, Ebrahem (2015) found that the opposite result multiplying shoots from Jojoba (Simmondsia chinensis) plant on MS medium supplemented with $1.00 \mathrm{mgl}^{-1} \mathrm{BA}$ in combination with $1.00 \mathrm{mgl}^{-1}$ IAA plus $40 \mathrm{mgl}^{-1}$ Adenine sulfate (Ads) was the best additives.

Table (6): Effect of some additives on shoot number per explant, shoot length, and number of leaves of Marrubium vulgare plant

\begin{tabular}{|c|c|c|c|c|}
\hline $\begin{array}{l}\text { Additive types } \\
0.2 \mathrm{mgl}^{-1}\end{array}$ & Parameters & $\begin{array}{c}\text { Shoot number per } \\
\text { explant }\end{array}$ & $\begin{array}{c}\text { Shoot } \\
\text { Length (cm) }\end{array}$ & $\begin{array}{l}\text { No. } \\
\text { leaves }\end{array}$ \\
\hline Control & & $2.13^{\mathrm{c}}$ & $1.50^{\mathrm{b}}$ & $10.75^{\mathrm{c}}$ \\
\hline Argininen & & $3.09^{\mathrm{b}}$ & $2.40^{\mathrm{b}}$ & $17.60^{\mathrm{b}}$ \\
\hline Asparagine & & $2.98^{\mathrm{b}}$ & $2.00^{\mathrm{b}}$ & $16.20^{\mathrm{b}}$ \\
\hline Pyridoxine & & $4.10^{\mathrm{a}}$ & $3.75^{\mathrm{a}}$ & $29.75^{\mathrm{a}}$ \\
\hline Thiamine & & $2.25^{\mathrm{c}}$ & $1.75^{\mathrm{b}}$ & $12.50^{\mathrm{c}}$ \\
\hline
\end{tabular}

Means followed by the same letter within each column are not significantly different at 0.05 level of probability according to Duncan's multiple range test

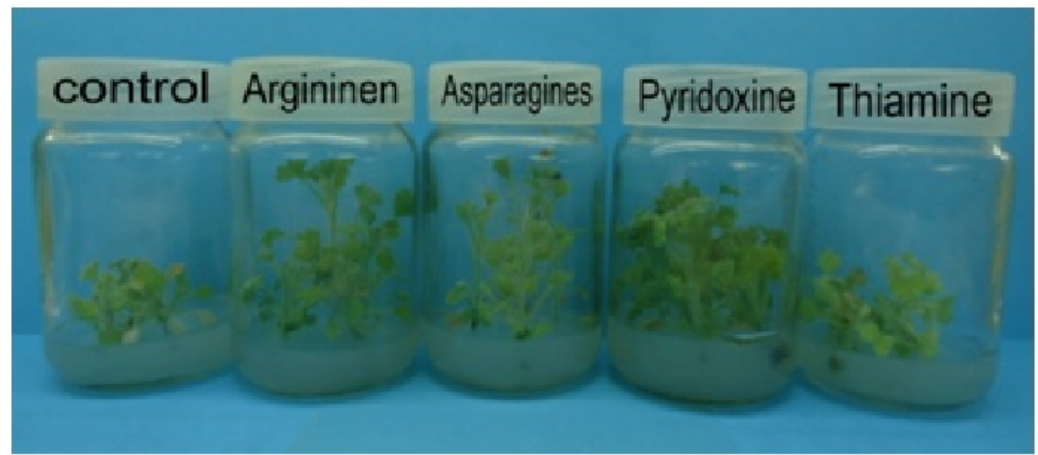

Fig. (3): Effect of additives on Marrubium vulgare plant

\section{Effect of pyridoxine concentration:}

Data presented in Table (7) showed that using 0.30 $\mathrm{mgl}^{-1}$ of pyridoxine resulted in the highest values of shoot number per explant, shoot length, and number of leaves. There were no significant differences among this concentration of pyridoxine of $0.30 \mathrm{mgl}^{-1}$ and other concentrations for shoot number per explants, shoot length, and number of leaves. The lowest values for all studied traits were recorded with control. Abdallah (2012) found that $0.30 \mathrm{mgl}^{-1}$ of pyridoxine resulted in the highest number of shoots, shoot length, number of leaves and number of leaves/shoot of Capparis spinosa. Also, Abdallah (2017) found that $0.40 \mathrm{mgl}^{-1}$ thiamine achieved the highest values of number of shoots, shoot length, number of leaves and number of leaves/shoot on Origanum syriacum. 
Table (7): Effect of different pyridoxine concentrations on shoot number per explant, shoot length, and number of leaves of Marrubium vulgare plant

\begin{tabular}{cccc}
\hline $\begin{array}{c}\text { Pyridoxine Con. } \\
\text { mgl }^{-1}\end{array}$ & Parameters & $\begin{array}{c}\text { Shoot number } \\
\text { per explant }\end{array}$ & $\begin{array}{c}\text { Shoot } \\
\text { Length } \\
(\mathbf{c m})\end{array}$ \\
\hline Control & $2.20^{\mathrm{b}}$ & $1.25^{\mathrm{c}}$ & $\begin{array}{c}\text { No. } \\
\text { leaves }\end{array}$ \\
$\mathbf{0 . 1 0}$ & $2.65^{\mathrm{b}}$ & $1.75^{\mathrm{bc}}$ & $10.75^{\mathrm{c}}$ \\
$\mathbf{0 . 2 0}$ & $2.68^{\mathrm{b}}$ & $2.50^{\mathrm{b}}$ & $13.25^{\mathrm{bc}}$ \\
$\mathbf{0 . 3 0}$ & $3.72^{\mathrm{a}}$ & $3.40^{\mathrm{a}}$ & $16.00^{\mathrm{b}}$ \\
$\mathbf{0 . 4 0}$ & $2.50^{\mathrm{b}}$ & $2.00^{\mathrm{bc}}$ & $25.20^{\mathrm{a}}$ \\
\hline
\end{tabular}

Means followed by the same letter within each column are not significantly different at 0.05 level of probability according to Duncan's multiple range test

\section{Rooting stage:}

\section{Effect of medium strength and auxin type:}

Data in Table (8) show significant effect for MS medium strength and type of auxin on shoot number per explant, shoot length, number of main roots and root length of Marrubium vulgarem. The highest values were recorded with application of full strength medium with IBA or half strength medium with NAA at $1.00 \mathrm{mgl}^{-}$ ${ }^{1}$. These results are in agreement with El-Beyrouthy et al.
(2015) who obtained high rooting response of shoots with IBA on full MS medium for $O$. syriacum. On the other hand Arafeh et al. (2003), Oluk and Cakir (2009) observed that plants were rooted on $1 / 2$ strength MS medium supplemented with0.10 - $2.00 \mathrm{mgl}^{-1} \mathrm{IBA}$ for Origanum species. Also, Soni et al. (2014) found that MS supplemented with IAA enhanced the roots parameters on Lavandula aungustifolia.

Table (8): Effect of MS medium strength and auxin type on shoot number per explant, shoot length, number of main roots, and root length of Marrubium vulgare plant

\begin{tabular}{|c|c|c|c|c|c|}
\hline \multicolumn{2}{|l|}{ Treatments } & \multirow{2}{*}{$\begin{array}{c}\text { Shoot number } \\
\text { per explant }\end{array}$} & \multirow{2}{*}{$\begin{array}{l}\text { Average shoot } \\
\text { Length } \\
\text { (cm) }\end{array}$} & \multirow{2}{*}{$\begin{array}{c}\text { No. } \\
\text { Main Roots }\end{array}$} & \multirow{2}{*}{$\begin{array}{c}\text { Root } \\
\text { Length } \\
\text { (cm) }\end{array}$} \\
\hline Medium strength & $\begin{array}{c}\text { Type of Auxin at } \\
1 \mathrm{mgl}^{-1}\end{array}$ & & & & \\
\hline \multirow{4}{*}{ Full } & Control & $1.67^{\mathrm{cd}}$ & $2.70^{\mathrm{d}}$ & $1.00^{\mathrm{d}}$ & $1.00^{\mathrm{cb}}$ \\
\hline & IAA & $2.67^{\mathrm{bcd}}$ & $5.00^{\mathrm{c}}$ & $3.37^{b}$ & $2.00^{\mathrm{b}}$ \\
\hline & IBA & $3.75^{\mathrm{ab}}$ & $8.53^{\mathrm{a}}$ & $5.73^{\mathrm{a}}$ & $12.00^{\mathrm{a}}$ \\
\hline & NAA & $3.00^{\mathrm{bc}}$ & $5.13^{\mathrm{c}}$ & $1.43^{\mathrm{cd}}$ & $2.00^{\mathrm{b}}$ \\
\hline \multirow{4}{*}{ Half } & Control & $1.67^{\mathrm{cd}}$ & $2.00^{\mathrm{d}}$ & $1.00^{\mathrm{d}}$ & $1.00^{\mathrm{cb}}$ \\
\hline & IAA & $2.00^{\mathrm{cd}}$ & $2.60^{\mathrm{d}}$ & $2.50^{\mathrm{bc}}$ & $2.00^{\mathrm{b}}$ \\
\hline & IBA & $2.25^{\mathrm{cd}}$ & $2.73^{d}$ & $2.95^{\mathrm{b}}$ & $2.25^{\mathrm{b}}$ \\
\hline & NAA & $4.50^{\mathrm{a}}$ & $7.38^{b}$ & $5.13^{\mathrm{a}}$ & $11.00^{\mathrm{a}}$ \\
\hline \multirow{4}{*}{ Quarter } & Control & $1.67^{\mathrm{cd}}$ & $1.73^{\mathrm{d}}$ & $0.67^{\mathrm{d}}$ & $0.67^{\mathrm{c}}$ \\
\hline & IAA & $1.67^{\mathrm{cd}}$ & $2.43^{\mathrm{d}}$ & $1.33^{\mathrm{cd}}$ & $1.33^{\mathrm{cb}}$ \\
\hline & IBA & $1.33^{\mathrm{d}}$ & $2.57^{\mathrm{d}}$ & $1.70^{\mathrm{cd}}$ & $1.67^{\mathrm{cb}}$ \\
\hline & NAA & $1.67^{\mathrm{cd}}$ & $2.90^{\mathrm{d}}$ & $1.57^{\mathrm{cd}}$ & $1.67^{\mathrm{cb}}$ \\
\hline
\end{tabular}

Means followed by the same letter within each column are not significantly different at 0.05 level of probability according to Duncan's multiple range test 
Effect of medium strength, auxin type and auxin concentrations:

Data in Table (9) and Figs. (4 \& 5) show that the highest significant values of shoot number per explant, shoot length, number of main roots and root length were recorded with the application of full strength medium with $1.00 \mathrm{mgl}^{-1}$ IBA followed by half strength medium with NAA at $1.50 \mathrm{mgl}^{-1}$ of Marrubium vulgare. These results are in agreement with the findings of Oluk and Cakir (2009) on Origanum sipyleum who found that full MS medium supplemented with $0.50 \mathrm{mgl}^{-1}$ (IBA) had the highest root number and root length. However, Arafeh et al. (2003) found that MS supplemented with 0.80 $\mathrm{mgl}^{-1}$ IAA achieved the highest number of roots on $O$. syriacum plant.

Table (9): Effect of media strength and auxin types on shoot number per explant, shoot length, number of main roots, and root length of Marrubium vulgare plant

\begin{tabular}{|c|c|c|c|c|c|c|}
\hline \multicolumn{2}{|l|}{ Treatments } & Parameters & \multirow{2}{*}{$\begin{array}{c}\text { Shoot } \\
\text { number per } \\
\text { explant }\end{array}$} & \multirow{2}{*}{$\begin{array}{c}\text { Average } \\
\text { shoot } \\
\text { Length }(\mathrm{cm})\end{array}$} & \multirow{2}{*}{$\begin{array}{c}\text { No. main } \\
\text { Root }\end{array}$} & \multirow{2}{*}{$\begin{array}{l}\text { Root length } \\
\text { (cm) }\end{array}$} \\
\hline Medium type & Type of auxin & Auxin con. & & & & \\
\hline \multirow{5}{*}{ Full } & \multirow{5}{*}{ IBA } & Control & $2.00^{\mathrm{b}}$ & $5.17^{\mathrm{b}}$ & $1.00^{\mathrm{d}}$ & $0.67^{\mathrm{d}}$ \\
\hline & & 0.50 & $2.67^{\mathrm{b}}$ & $6.70^{\mathrm{ab}}$ & $2.67^{\mathrm{c}}$ & $2.27^{\mathrm{c}}$ \\
\hline & & 1.00 & $5.00^{\mathrm{a}}$ & $8.50^{\mathrm{a}}$ & $7.25^{\mathrm{a}}$ & $7.88^{\mathrm{a}}$ \\
\hline & & 1.50 & $3.25^{\mathrm{b}}$ & $7.08^{\mathrm{ab}}$ & $4.25^{\mathrm{b}}$ & $5.22^{\mathrm{b}}$ \\
\hline & & 2.00 & $3.00^{\mathrm{b}}$ & $6.28^{\mathrm{b}}$ & $2.50^{\mathrm{c}}$ & $2.63^{\mathrm{c}}$ \\
\hline \multirow{5}{*}{ Half } & \multirow{5}{*}{ NAA } & Control & $2.67^{\mathrm{b}}$ & $6.23^{\mathrm{b}}$ & $1.00^{\mathrm{b}}$ & $0.67^{\mathrm{c}}$ \\
\hline & & 0.50 & $3.33^{\mathrm{ab}}$ & $6.40^{\mathrm{b}}$ & $2.00^{\mathrm{b}}$ & $2.17^{\mathrm{b}}$ \\
\hline & & 1.00 & $3.00^{\mathrm{b}}$ & $6.73^{\mathrm{b}}$ & $2.50^{\mathrm{b}}$ & $2.88^{\mathrm{b}}$ \\
\hline & & 1.50 & $4.60^{\mathrm{a}}$ & $8.40^{\mathrm{a}}$ & $9.40^{\mathrm{a}}$ & $6.78^{\mathrm{a}}$ \\
\hline & & 2.00 & $2.50^{\mathrm{b}}$ & $6.00^{\mathrm{b}}$ & $2.00^{\mathrm{b}}$ & $2.15^{\mathrm{b}}$ \\
\hline
\end{tabular}

Means followed by the same letter within each column are not significantly different at 0.05 level of probability according to Duncan's multiple range test

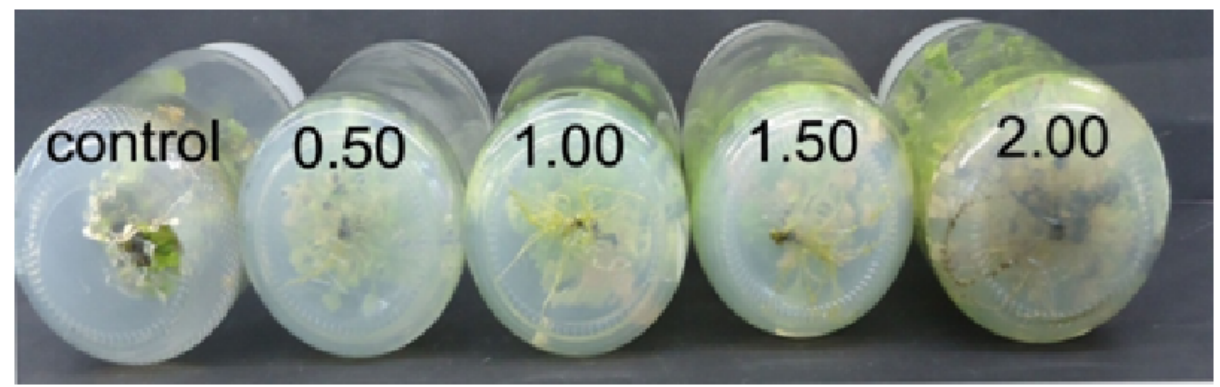

Fig. (4): Effect of IBA concentrations $\left(\mathrm{mgl}^{-1}\right)$ on full MS medium on root formation of Marrubium vulgare

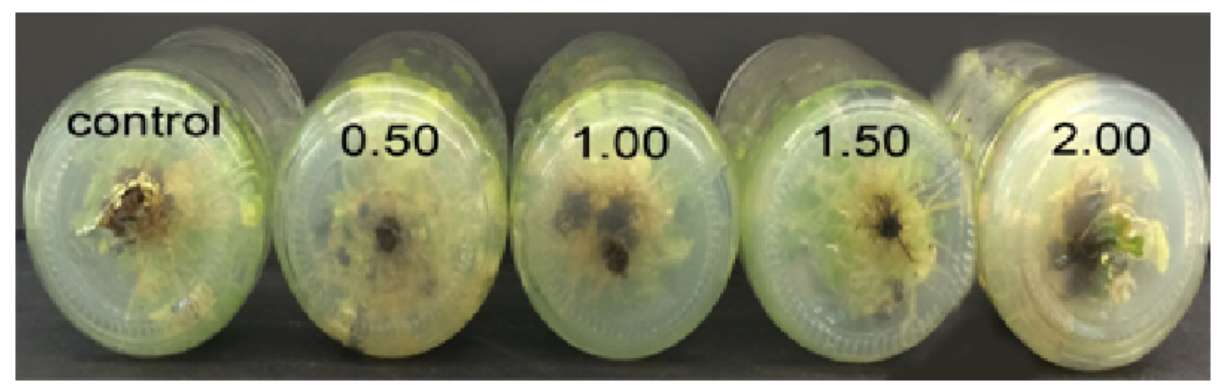

Fig. (5): Effect of NAA concentrations $\left(\mathrm{mgl}^{-1}\right)$ on half MS medium on root formation of Marrubium vulgare plant 


\section{Acclimatization stage:}

Marrubium vulgare was successfully acclimatized by using a combination of peatmoss, sand and vermiculite at a rate $1: 1: 1(\mathrm{v} / \mathrm{v} / \mathrm{v})$, respectively (Fig. 1). Similarly, Arafeh et al. (2003) and El-Beyrouthy et al. (2015) found that the mixtures of peat and perlite at a ratio of $1: 1$ or $1: 2(\mathrm{v} / \mathrm{v})$ were selected as the most suitable media for transplanting or adaptation of Marrubium vulgare plantlets.

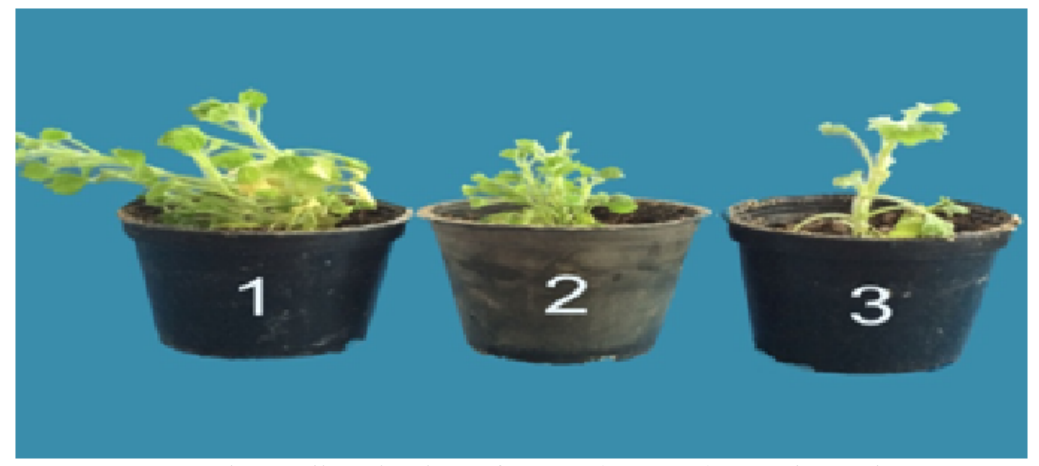

Fig (6): The acclimatization of Marrubium vulgare plant where:

1) $1: 1: 1(\mathrm{v} / \mathrm{v} / \mathrm{v})$ peat moss, vermiculite and sand

2) $1: 1: 1(\mathrm{v} / \mathrm{v} / \mathrm{v})$ peat moss, vermiculite and perlite

3) $1: 1(\mathrm{v} / \mathrm{v})$ peat moss, vermiculite

\section{CONCLUSION}

In this study a suitable protocol was developed for in vitro micropropagation of Marrubium vulgare. Firstly, establishment of in vitro shoots from shoot tip explants on MS medium. Then multiply, the shoots on MS medium $+1.00 \mathrm{mgl}^{-1} \mathrm{Kin}+0.10 \mathrm{mgl}^{-1}$ NAA. Moreover, rooting the shoots on full strength MS medium with $1.00 \mathrm{mgl}^{-1}$ IBA or half strength MS medium with $1.50 \mathrm{mgl}^{-1} \mathrm{NAA}$. Finally, hardening the rooted shoots in greenhouse in pots containing mixture of peatmoss, vermiculite and washed sand $(1: 1: 1 \mathrm{v} / \mathrm{v} / \mathrm{v})$.

\section{REFERENCES}

Abdallah, S. A. S. (2012). Propagation of some medicinal and aromatic plants using tissue culture technique. PhD Thesis, Faculty of Environmental Agriculture Sciences, Suez Canal University.

Abdallah, S. A. S., M. Y. A. Yakoup and M. Y. H. Abdalla (2017). Micropropagation of oregano (Origanum syriacum L.) through tissue culture technique. J. Plant Production, Mansoura Univ., 8(5): 635 -639.

Arafeh, R. M., M. S. Mahmoud and R. A. Shibli (2003). In vitro seed propagation of wild Syrian marjoram (Origanum syriacum L.) Adv. Hort. Sci., 17(4): 241-244.

Arikat, N. A., F. M. Jawad, N. S. Karam and R. A. Shibli (2004). Micropropagation and accumulation of essential oils in wild sage (Salvia fruticosa Mill.). Scientia Hort., 100: 193-202.

Bakhtiar, Z., M. H. Mirijalili and A. Sonboli (2016). In vitro callus induction and micropropagation of Thymus persicus (Lamiaceae), an endangered medicinal plant. Crop Breeding and Applied Biotecnology, 16: 48-54.
Chase, A. R. (1987). Compendium of ornamental foliage plant diseases. The American Phytopathological Society. Press. Minnesota, USA.

Desouza, M. M., R. A. P. Dejesus, V. C. Filho and V. Schlemper (1998). Analgesic profile of hydroalcoholic extract obtained from Marrubium vulgare. Phytomed, 5(2): 103107.

Duncan, D. B. (1955). Multiple range and multiple Ftest. Biometrics, 11: 1-42.

Ebrahem, S. S. A. (2015). Biotechnological studies on Jojoba using tissue culture technique. M. Sc. Thesis, Faculty of Environmental Agriculture Sciences, Suez Canal University.

El-Bardai, S., B. Lyoussi, M. Wibo and N. Morel (2004). Comparative study of the antihypertensive activity of Marrubium vulgare and of the dihydropyridine calciumantagonist amlodipine in spontaneously hypertensive rat. Clin Exp Hyprtens., 26(6): 465-474.

El-Bardai, S., N. Morel, M. Wibo, N. Fabre, G. Llabres, B. Lyoussi and L. Quetin (2003). The vasorelaxant activity of marrubenol and marrubiin from Marrubium vulgare. Plant Med., 69(1): 75-77.

El-Beyrouthy, M., G. Elian, C. Abou Jaoudeh and L. Chalak (2015). In vitro propagation of Origanum syriacum and Origanum ehrenbergii. Acta Hort., 19: 169-172.

Gamborg, O. L. (1968). Cells, Protoplasts, and Plant Regeneration in Culture. In: Manual of Industrial Microbiology and Biotechnology. A. L. Demain and N. A. Solomon, editors, Dept. of Nutrition \& Food Science, Mass. Inst. of Tech., Cambridge, Mass.

Ghazanfar, S. A. (1994). Handbook of Arabian Medicinal Plants. CRC Press, Boca Raton, FL, p. 265. 
Goleniowski, M. E., C. Flamarique and P. Bima (2003). Micropropagation of oregano (Origanum vulgare $\times$ Applii) from meristem tips. In vitro Cell. Dev. Biol. Plant., 39: 125-128.

Kadri, A., Z. Zarai, A. Bekir, N. Gharsallah, M. Damak and R. Gdoura (2011). Chemical composition and antioxidant activity of Marrubium vulgare L. essential loil from Tunisia. African Journal of biotechnology, 10(198): 39083914.

Khan, S., S. Naz and B. Saeed (2004). In vitro production of Cordyline terminalis for commercialization, Pakistan J. Bot., 36(4): 757-761.

Murashige, T. and F. Skoog (1962). Arevised medium for rapid growth and bioassays with tobacco tissue cultures. Physiol. Plant., 15: 473-497.

Nitsch, J. P. and C. Nitsch (1969). Haploid plants from pollen grains. Science, 163: 85-87.

Oana, C. T., F. Marcela and P. Maria (2008). Considerations regarding the effects of growth regulators over the "in vitro" morphogenetic reaction at Origanum vulgare L. J. Plant Develop., 15: 133-138.

Oluk, E. A. and A. Cakir (2009). Micropropagation of Origanum sipyleum L., an endemic medicinal herb of Turkey. African J. Bio., 8(21): 57695772.

Ozkum, D. (2007). In vitro shoot regeneration of oregano (Origanum minutiflorum O. Schwarz \& Davis). Hacettepe J. Biol. and Chem., 35(2): 97-100.

Ozudogru, E. A., E. Kaya, E. Kirdok and S. Issever-Ozturk (2011). In vitro propagation from young and mature explants of thyme (Thymus vulgaris and $T$. Longiculis) resulting in genetically stable shoots. In vitro Cell. Dev. Biol. Plant, 47: 309320.

Roman, R. R., A. F.Aharcon, L. A. Lara and S. J. L. Flores (1992). Hypoglycemic effect of plants used in Mexico as antidiabetics. Arch Med Res., 23(1): 59-64.

Sahpaz, S., N. Garbacki, M. Tits and F. Bailleul (2002). Isolation and pharmacological activity of phenylpropanoid esters from Marrubium vulgare. J. Ethnopharmacol, 79(3): 389-392.

SAS (2004). SAS/STAT User's Guide. SAS Institute Inc., Cary, N.C.

Schlemper, V., A. Ribas, M. Nicolau and V. C. Filho (1996). Antispasmodic effects of hydroalcoolic extract of Marrubium vulgare on isolated tissues. Phytomedicine, 3: 211216.

Soni, D. R., F. G. Sayyad and G. K. Sodhi (2014). Micropropagation studies in Lavandula aungustifolia. Bioscience, Bioengineering and Biotechnology, 1: 07-10.

Stulzer, H. K., M. P. Tagliari, J. A. Zampirolo, V. C. Filho and V. Schlemper (2006). Antioedematogenic effect of marrubiin obtained from Marrubium vulgare. J. Ethnopharmacol, 108(3): 379-392.

Weel, K. C. G., P. R. Venskutonis, A. Pukalskas, D. Gruzdiene and J. P. H. Linssen (1999). Antioxidant activity of horehound (Marrubium vulgare) grown in Lithuania. Fett/Lipid, 101(10): 395-400.

Wink, M. (2003). Evolution of secondary metabolites from an ecological and molecular phylogenetic perspective. Photochemistry, 64: 3-19.

Yavuz, D. O. (2015). Optimization of regeneration conditions and in vitro propagation of Sideritis stricta Boiss \& Heldr. International J. Biol. Macromol., 5478: 4 pages.

Yildirim, M. U. (2013). Micropropagation of Origanum acutidens (HAND - MAZZ) ietswaart using stem node explants. The Scientific World Journal, Article ID 276464: 3 pages.

Zuzarte, M. R., A. M. Dinis, C. Cavalerio, L. R. Salgueiro and J. M. Canhoto (2010). Trichomes, essential oils and in vitro propagation of Lavandula pedunculata (Lamiaceae). Industrial Crops and Products, 32: 580-587.

Harley, M. R., S. Atkins, A. L. Budantsev, P. D. Cantino, B. J. Conn, R. J. Grayer, M. M. Harley, R. P. J. de Kok, T. V. Krestovskaja, R. Morales, A. J. Paton and P. Olof Ryding (2004). "Labiatae" pages 167-275. In: Klaus Kubitzki (editor) and Joachim W. Kadereit (volume editor). The Families and Genera of VascularPlants volume VII. Springer-Verlag: Berlin; Heidelberg, Germany.

Wiesner, J. and M. Peikert (2013). Assessment report on Marrubium vulgare L., herba. European Medicines Agency, Committee on Herbal Medicinal Products (HMPC). EMA/HMPC/604273/2012.

Thorpe, T. A. (1981). Plant tissue culture: methods and applications in agriculture. 379 pp. New York Academic Press. 


\section{تطبيقات زراعة الأنسجة علي نبات الفراسيون}

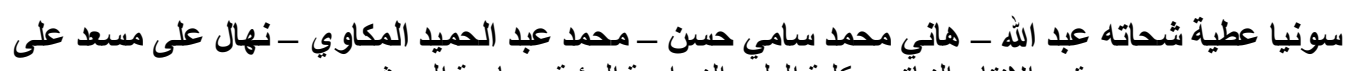

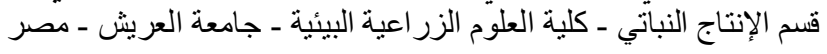

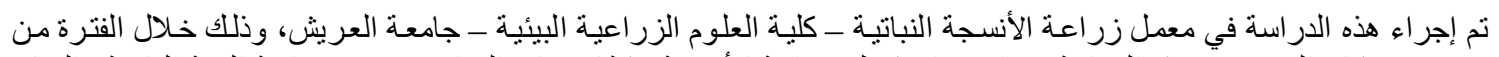

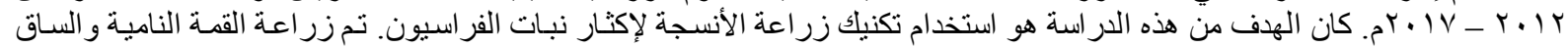

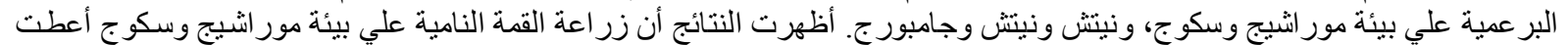

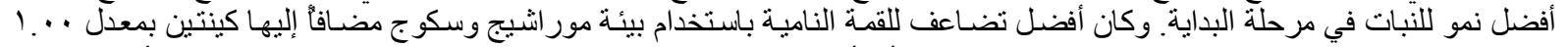

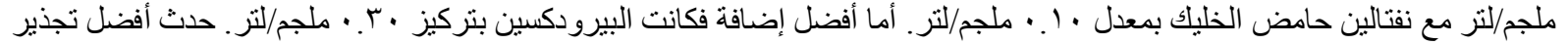

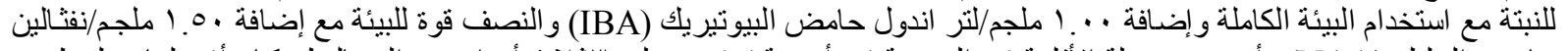

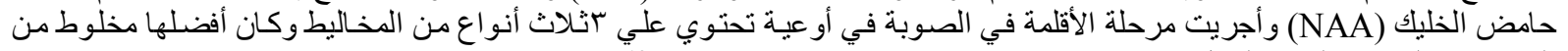

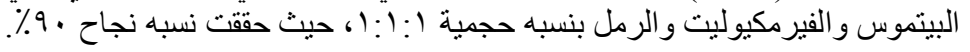

